\section{Härmistetty kuolema: pelonhallintaa zombi-kuvakirjoissa}

\author{
Susanne Ylönen
}

Kuolema ei ole lastenkirjallisuudessa epätavallinen aihe, ja sitä on myös tutkittu alalla kiitettävästi. Kuten Maria Tatar kirjoittaa, ovat sadut pitkään tarjonneet kauneutta, kauhua, inmeitä, väkivaltaa ja taikuutta, ${ }^{1}$ ja tätä seurailevat myöhemmät tutkimukset, joiden mukaan jopa väkivaltainen kuolema on lastenkirjallisuudessa selvästi läsnä2. Kuvakirjoissa, joita voidaan pitää ainakin osittain lastenkirjallisuuden alalajina, kuolemaa koskevien pelkojen käsittely on tosin varhaisempiin, opettavaisiin ja varottaviin lastenkirjoihin ja satuihin sekä nuorten kirjoihin verrattuna useimmiten lohdullisempaa, estetisoivaa. ${ }^{3}$
Estetisoinnilla tarkoitan tässä yhteydessä käsittelytapaa, joka johdattaa lukijan ajatukset pois itse kuolemasta tapahtumana ja keskittyy esimerkiksimuistamisen tärkeyteen, haudalle laskettaviin kukkiin ja kuoleman jälkeisen elämän kuvauksiin ja yleiseen lohduttavuuteen ${ }^{4}$. Vaikka kuvakirjojen historiaan mahtuu myös Heinrich Hoffmannin Jörö-Jukan (1845) kaltaisia groteskia kerrontatapaa hyödyntäviä teoksia ja Edward Goreyn goottihenkisiä kuvaelmia sekä Wolf Erlbruchin Duck, Death and the Tulip (2007) -kirjan kaltaisia danse macabre -traditioon linkittyviä teoksia ${ }^{5}$, ovat useimmat kuolemaa käsittelevät kuvakirjat myös humoristisuudessaan söpöileviä. Käpy ry:n kokoaman kuolema-aiheisen kuvakirjalistan tehtävä esimerkiksi näyttäisi olevan auttaa perheen pienimpiäkin elämään kuolemaa koskevan tiedon ja kuoleman kokemusten kanssa.

Lohdullisuuteen pyrkivien kuvakirjojen lisäksi kuolema on keskeinen teema myös kauhugenressä. Siellä sen käsittely ei tosin ehkä herätä ensimmäisenä ajatuksia lohduttavuudesta, sillä genren keskeisin merkitsijä on pelon ja inhon sekaisen kauhun tunteen herättäminen ja välittäminen - usein hirviöhahmojen kautta ${ }^{6}$. Kuolleista palaaminen kummituksena ei kuulu kuoleman jälkeistä elämää kaunisteleviin selityksiin, ja vielä vähemmän lohdullista on ajatella, että joku itselle rakas palaisi takaisin zombina. Zombithan ovat hirviömäisiä, outoja kategoriarikkomuksia, jotka haastavat tavallisen kuolemisen ja palauttavat kuolemaan liittyvät ajatukset yhä uudelleen kuoleman ja elämän rajankäynnin likaisimpaan ja pelottavimpaan vaiheeseen, varsinaiseen kuolemiseen ja sitä seuraavaan mätänemiseen. Kauhugenren yhteydessä lastenkirjallisuuden sisältämiä kuoleman kuvauksia ovat käsitelleet esimerkiksi Chloé Germaine Buckley (2018), Michelle Ann Abate (2013) ja Peter Kosten- 
niemi (2017). Buckley keskittyy nomadisen subjektin kuvauksiin lasten gotiikassa ja tarkastelee esimerkiksi Darren Shanin Zom-B kirjasarjaa. Abate puolestaan käsittelee lastenkirjallisuudessa esiintyviä murhakuvauksia ja tarttuu Lumikki-sadun, Tarzanin ja Neiti Etsivien lisäksi myös Stacey Jayn Death High -sarjaan ja sen nuorille suunnattuihin zombikuvauksiin. Kostenniemi taas tarkastelee Angela Sommer-Bodenburgin Pikku Vampyyri -kirjoja.

Vaikka nämä tutkimukset puolustavat omalla tavallaan kauhistuttavan kuoleman läsnäoloa lastenkirjallisuudessa liittämällä sen esimerkiksi länsimaisen yhteiskunnan ylipäätään murhia kohtaan osoittamaan kiinnostukseen ${ }^{7}$ ja lasten toimijuuden ja suojeltavuuden välillä tasapainoilevaan asemaan $^{8}$, rajataan kauhukertomuksille ominainen tapa käsitellä kuolemaa usein ennemmin yliluonnollisen viehätyksen ja taikauskon piiriin kuuluvaksi, fiktiiviseksi viihteeksi kuin vakavasti otettavaksi kuoleman käsittelyksi. Jos taikauskon ja yliluonnolliseen kohdistuvien uskomusten määritellään liittyvän sellaisiin käsityksiin, jotka eivät vastaa nykyisiä tieteellisiä selitysmalleja vaan jotka ovat usein henki- lökohtaisempia ja intuitiivisia ja vaihtelevat spontaaneista, epämääräisistä tuntemuksista kulttuurisesti opetettuihin tai välitettyihin uskomuksiin ${ }^{9}$, voidaan kuitenkin ajatella, että kauhuviihde tarjoaa omalla tavallaan väylän käsitellä kuolemaan liittyviä, enemmän tai vähemmän taikauskoisia käsityksiä ja pelkoja. Pelkojen käsittelytapaa ei vain kauhun yhteydessä ehkä pidetä vakavasti otettavana tai terapeuttisena vaan pikemminkin sensaatiohakuisena fantasiana.

Hyvän esimerkin tällaisesta ei-vakavasti otettavasta kuoleman käsittelystä tarjoavat kuvakirjojen zombit. Äkkiseltään zombi, jonka hahmossa konkretisoituu väkivaltaisen kuoleman ajatus, ei ehkä ylipäätään tuntuisi sopivan suojelueetoksen ja lapsiystävällisyyden ajatuksen varaan rakentuneeseen lastenviihteeseen ${ }^{10}$, tai ainakaan kuvakirjoihin, jotka on usein suunnattu alle kouluikäisille tai vasta koulunkäynnin aloittaneille lapsille. Zombit ovat kuitenkin tällä hetkellä populaarikulttuurin ehkä suosituimpia hirviöhahmoja tai ainakin suositumpia kuin koskaan aiem$\min ^{11}$. Kansoittaessaan elokuvien, kirjallisuuden, sarjakuvien, videopelien ja fanikulttuurisen toiminnan lisäksi myös kasvavassa määrin erilaisten kulutushyödykkeiden ja puhelinsovellusten kentän zombit ovat väistämättä lipuneet myös lastenkulttuuriin ja lapsille osoitettuun tai lapsiin yhdistettyyn kirjallisuuteen - joko varsinaisina lasten kuvakirjoina tai humoristisina parodioina, lastenkulttuuriin linkittyvänä aikuisten viihteenä, crossover-kirjallisuutena ${ }^{12}$.

Tämä artikkeli, jonka tausta on kauhun ja lastenkirjallisuuden sekä estetiikan tutkimuksessa, tarkastelee sitä, miten zombin hahmossa havainnollistuva ruma ja väkivaltainen kuolema on tuotu kuvakirjoihin. Artikkelissa käytetty aineisto kattaa 15 vuosina 2010-2017 ilmestynyttä kuvakirjaa (ks. primäärilähteet). Suurin osa on haettu Amazon.comista hakusanoilla "zombie picture book" vuoden 2017 aikana. Hakualustan ja -kielen vuoksi kaikki kirjat ovat englanninkielisiä. Niiden kohdeyleisön ikä puolestaan vaihtelee tekijöiden mukaan 6+ -määrityksistä aikuislukijoihin. Suomalaisia zombiaiheisia kuvakirjoja en löytänyt, vaikka aihe näkyy kyllä vanhemmille lapsille suunnatuissa, kuvitetuissa lastenkirjoissa, kuten Veera Salmen Pulu Boin ja Ponin tsompikirjassa (2015) ja Harri Istvan Mäen kirjoissa Meluavat zombikalsarit (2017) ja Zombikirja (2018). 
Ennen kaikkea tämä artikkeli paneutuu niihin esteettisiin käsittelytapoihin, joilla zombien pelottavuutta pyritään kuvakirjojen piirissä hallitsemaan. Näkökulmassa painottuu kaunistelevan estetisoinnin lisäksi humoristinen, alentava ruumiillistaminen, jota käsittelen taidefilosofi Carolyn Korsmeyeriin ${ }^{13}$ nojautuen esteettisenä härmistämisenä. Tarkastelemalla kuvakirjoissa zombiudelle annettuja selityksiä ja zombien esteettisiä käsittelytapoja artikkeli pyrkii valottamaan suhdettamme yliluonnollisiin ilmiöihin niiden populaarikulttuurisen hallinnan kautta. Se painottaa sitä, että esteettinen härmistäminen on varsin yleinen tapa hallita tuntemattomiin ja kauhistuttaviin asioihin, kuten kuolemaan, liittyviä pelkoja. Näiltä osin argumentti seurailee Aby Warburgin näkemyksiä, joiden mukaan hirviöiden kuvallistaminen voi näyttäytyä eräänlaisena pelkojen kesyttämisenä ${ }^{14}$.

\section{Härmistetty kuolema}

"Esteettinen härmistäminen" on termi, joka kuvaa kauhistuttavien asioiden rumentavaa, alentavaa, outouttavaa ja naurettavaksi tekevää käsittelyä. Taiteen tutkimuksen saralla termiä "the sublate", härmistyminen, on käyttänyt esimerkiksi taidefilosofi Carolyn Korsmeyer, joka hahmottelee siitä ylevän käsitteen vastakohtaa kirjassaan Savoring Disgust: The Foul and the Fair in Aesthetics (2011). Korsmeyerin mukaan tätä alkemian piiristä kumpuavaa käsitettä voidaan käyttää metaforallisesti kuvaamaan pientä, nöyrää, ruumiillista ja inhottavaa kokemusta, sekä tällaisten kokemusten filosofista potentiaalia.

Suomenkielessä sanan "sublate" vastine, "härmistyminen", kuvaa aineen muutosta kaasumaisesta kiinteäksi, eli se on fysikaalisen sublimoitumisen vastakohta. Mikäli sublimoitumisen voidaan Korsmeyeria seuraillen ajatella vastaavan metaforallisesti estetiikan saralla käytettyä ylevän käsitettä, joka kuvaa rajattomuuden, mystisyyden ja voimallisuuden tunnetta, voidaan härmistymisen ajatella korostavan ruumiillisen ja inhottavan kokemuksen ymmärrystä lisäävää potentiaalia. ${ }^{15}$ Pelonhallinnan keinona esteettinen härmistäminen, joka havainnollistuu paitsi kuvan suttaamisessa myös naurettavaksi piirtämisessä ja karnevalistisessa esittämisessä yleensä, liittyy näin ollen myös taikauskoisiin toimintatapoihin ja esimerkiksi animismiin, joka on länsimaissa yhdistetty Freudista ja Piagetista lähtien paitsi primi- tiivisiin kansoihin, myös nimenomaan lapsiin. ${ }^{16}$

Estetiikan piirissä vastausta ruman, inhottavan ja pelottavan viehätykselle on aiemmin lähestytty muun muassa termien, kuten groteskin ja abjektin kautta. Näistä kummallakin on oma historiallinen viitekehyksensä tai syntykontekstinsa ja pääasiallinen käyttöyhteytensä, sekä alakohtainen teoreettis-historiallinen painolastinsa. Groteski esimerkiksi on pitkälti taidehistoriallinen käsite ja se on totuttu yhdistämään asioihin, kuten liioitteluun ja vääristämiseen, yhteensopimattomien asioiden yhdistelyyn, grotto-maalauksiin, fantastisiin kauhukuviin ja karikatyyreihin. ${ }^{17}$ Abjekti puolestaan on tullut tunnetuksi ennen kaikkea psykoanalyyttisesti suuntautuneen filosofin ja kirjailijan, Julia Kristevan, työn myötä ja sitä on sovellettu eritoten nykytaiteen piirissä, missä sillä on kuvattu muun muassa erinäisten eritteiden affektiivisella voimalla leikitteleviä teoksia. ${ }^{18}$ Näiden termien ohella humoristisia zombikuvauksia voidaan lisäksi lähestyä myös kuoleman karnevalisointina. Karnevalisointi kietoutuu olennaisella tavalla yhteen realistisen groteskin, eli groteskin naurettavan, sosiaalisen ja ruumiillisen muodon kanssa, ja se 
kohdistuu usein juuri siihen, mitä pidetään pyhänä ja mystisenä: moraalisiin kieltoihin, jumalan ja inmisen valtaan, auktoriteetteihin ja kuolemaan sekä kuoleman jälkeisiin palkintoihin ja rangaistuksiin. Nurinpäin kääntävän lähestymistapansa vuoksi karnevaalinauru on eräänlainen hetkellinen voitto näihin asioihin kohdistuvista pelosta.

Esteettinen härmistäminen tuo näiden käsitteiden rinnalle esteettisen esittämisen ja arvottamisen prosessiluonnetta korostavan käsitteen. Rumiin ja naurettaviin kauhuhahmoihin, kuten zombeihin sovellettuna se kuvaa nähdäkseni "rumentamista" ja "abjektointia" tai "groteskiksi tekemistä" paremmin sitä, miten vapaasti ilmassa leijuvat, muodottomat pelot ja toiveet voidaan tiivistää ja konkretisoida, tuoda lähelle ja tehdä hallittaviksi inhon ja huumorin kautta. Näin käsitteellistettynä ja käytettynä termi on siis uusi ja suhteellisen historiaton, vaikka sen kuvaamaa ilmaisullista prosessia voidaan tarkastella jonakin yleisinhimillisenä ja siten lähes ajattomana asiana. Tavallaan tällaista kuvantamisen mekaniikkaa pelkojen hallinnan tapana kuvasi jo Aby Warburg esittäessään, että hirviökuvat syntyvät peloista, joille kuvallinen muoto antaa pai- kan yhteisön maailmankuvassa. Warburg puhuu tästä kuvien tuottamisen mekaniikasta kesyttämisenä, tai humanisaationa. ${ }^{19}$ Itse kuitenkin jakaisin pelkojen kesyttämistä kuvaavan humanisaation vielä kahteen eri hallinnantapaan: estetisointiin ja esteettiseen härmistämiseen. Vaikka sekä estetisoinnissa että esteettisessä härmistämisessä on kyse jonkin hallitsemattomalta ja ylivoimaiselta tuntuvan tai jopa pyhän asian konkretisoimisesta ja hallittavaksi tekemisestä, käsittelytavat eroavat toisistaan siinä, että toinen tarttuu kauniiksi ja toinen inhottavaksi ja/tai naurettavaksi tekemiseen.

Kuvaksi tekeminen ei kuitenkaan tarkoita sitä, että kuvattu pelottava tai pyhä asia palautuisi yksioikoisesti ainoastaan hallituksi "kuolleeksi esineeksi". Kuten Petri Vuojala huomauttaa, voi "magian ruokkima todellisuussuhde" Warburgin ajattelussa muuttaa kuvat myös aktiivisiksi toimijoiksi. Humanisaation rinnalla Warburg näkeekin myös demonisoivan tai villiyttävän tendenssin, logiikkaa vastustavan ja silmän luomaa etäisyyttä yhteenkurovan, minää ja objektia maagisesti lähentävän lähestymistavan, jonka hän liittää "foobiseksi refleksiksi" kutsumaansa ihmisen alkuperäiseen, pelokkaaseen olotilaan. ${ }^{20}$
Samantyyppisillä, evolutiivisilla selityksillä on pyrittyavaamaanmyöskauhuviihteenviehätystä. ${ }^{21}$ Jos magia voidaan mieltää aktiiviseksi, todellisuutta aktiivisesti esimerkiksi erilaisten rituaalien tai taikojen kautta muokkaamaan pyrkiväksi hengellisyyden muodoksi ${ }^{22}$, voidaan esteettisen härmistämisen prosessi sekin hahmottaa tietyllä tapaa taikauskoiseksi toiminnaksi, jossa hallitsemattomat asiat, kuten tulevaisuuteen, omaan voimattomaan asemaan tai henkiin kohdistuvat pelot ja toiveet ohjataan tai alennetaan tiettyyn materiaaliin. Kuten Christopher Bracken huomauttaa, ovat metaforat taikauskoisessa tulkinnassa suoraan yhteydessä fyysiseen todellisuuteen, jolloin voidaan ajatella, että todellisuuteen voidaan vaikuttaa diskursiivisesti2 ${ }^{23}$ esimerkiksi juuri kuvien käsittelyn kautta. Puhutussa ja kirjoitetussa kielessä sadattelulla ja kiroamisella voidaan ajatella olevan samanlainen funktio. ${ }^{24}$

\section{Zombeissa ja zombikuvakirjoissa havain-} nollistuva härmistetty kuolema

Tämä härmistävän kuolemanhallinnan ja maagisten uskomusten yhteys konkretisoituu zombeissa, jotka jo historialliselta taustaltaan linkittyvät magiaan. Haitilaisessa 
voodoossa, johon zombin hahmon juuret voidaan jäljittää, zombilla viitataan elävään kuolleeseen tai henkilöön, jolta on voodoo-papin avulla varastettu tämän oma tahto. ${ }^{25}$ Maailmanlaajuisesti tunnetuksi kauhuhahmoksi zombi kasvoi kuitenkin Amerikkalaisen elokuvateollisuuden kautta. 1930-1960 amerikkalaiset zombielokuvat ja -näytelmät tarttuivat juuri voodoon eksotiikkaan ja kuvasivat sen yksipuolisesti eräänlaiseksi mustaksi magiaksi, mikä palveli Yhdysvaltoja paitsi viihteenä, myös Haitia toiseuttavana, saarivaltion miehitystä puolustavana propagandana. ${ }^{26}$ Myöhemmät elokuva-adaptaatiot George A. Romeron zombitrilogian vanavedessä muuttivat zombin hahmon lihaa syöväksi eläväksi kuolleeksi ja lisäsivät zombin kuvaan esimerkiksi apokalyptiset sairausepidemiat. Nykymuodossaan zombia määrittävätkin useimmiten virustartunta, kuolleesta paluu ja lihanhimo.

Kuvakirjojen tapa esittää zombius seurailee näitä populaarikulttuuriin vakiintuneita esitystapoja, mutta mukana on myös lapsille suunnatuille narratiiveille tyypillistä söpöilyä ja zombiuden leikiksi tulkitsevia selityksiä. Kuvitelmina, leikkinä tai epäaitoina, satumaisina uskomuksina zombit esitetään tämän aineiston osalta neljässä kirjassa. Näissä esityksissä myös zombeille ominainen lihanhimo typistyy pelkäksi retoriseksi aivojen himoitsemiseksi, eikä kuolemaa tai kuolemasta paluuta välttämättä kuvata niissä muuten kuin viitteellisesti, hautakivien ja harmaan vihertävän ihonvärin kautta. Kiinnostavan huomion muodostaa myös esimerkiksi se, että tässä artikkelissa analysoiduista 15 kuvakirjasta neljä kuvaa zombiutta epidemiamaisesti leviävänä tautina siinä missä vain yksi kirjoista viittaa suoraan taikuuteen zombiuden syynä. ${ }^{27}$

Populaarikulttuurisen historiansa aikana zombin hahmo on muuntautunut tahdottomasta ruumiista 2000-luvun nopeasti liikku-

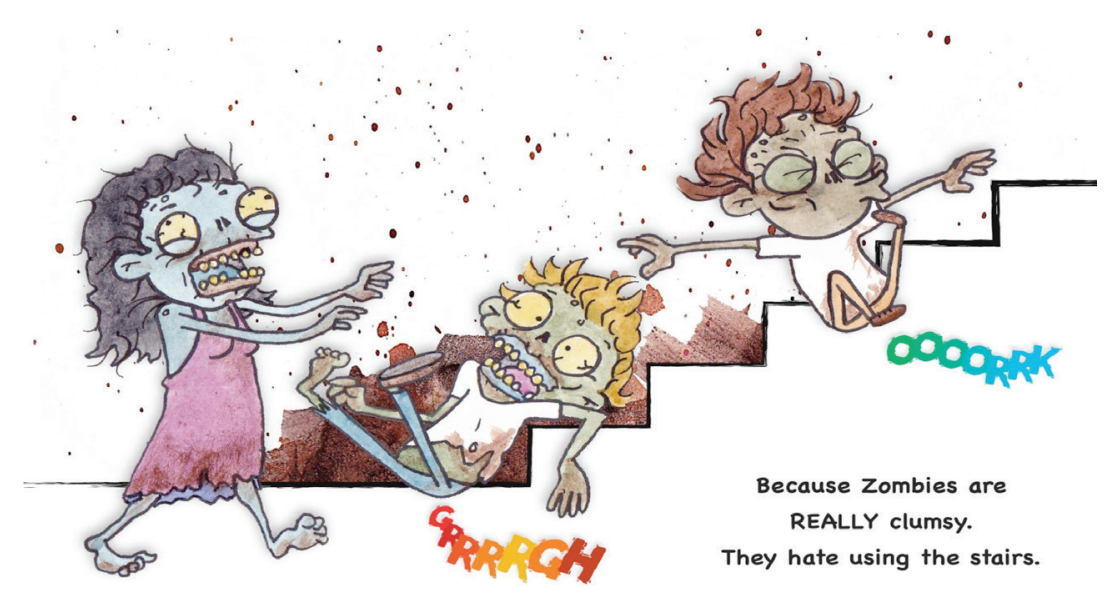

vaksi saalistajaksi ${ }^{28}$, mutta ikonisimmillaan zombi on edelleen jäykästi ja laahaavan kömpelösti liikkuva, tyhjäpäinen ja likainen vastakuollut. Zombiksi ei siis tavallisesti lasketa ketä tahansa elävää kuollutta, kuten Jeesusta tai Frankensteinia ${ }^{29}$, vaan vain ja ennen kaikkea sellainen elävä kuollut, jolta puuttuu sielu, vapaa tahto ja persoonallisuus, sekä useimmiten myös äly ja humaanius ${ }^{30}$. Kuvakirjazombien kohdalla tämä älyn, tahdon ja persoonallisuuden puute korostuu. Kuvakirjazombit kuvataan melkein poikkeuksetta kuolaavina, laahaavasti kävelevinä ja yksinkertaisina. Michael Kloranin Zombies: The Stinking Dead (2014) esimerkiksi pilailee zombien kustannuksella

Kuva 1. Kirjasta Mike Kloran, Zombies: The Stinking Dead, (c) Mike Kloran. 
selittäessään, että zombeja on hyvä paeta yläkertaan, koska ne ovat niin kömpelöitä, etteivät ne mielellään käytä portaita.

Kuvakirjat kuvaavat zombit kuitenkin myös usein inhimillisinä ja samastuttavina, mikä poikkeaa yllä mainitusta epähumaaniuden kaavasta. Yli puolet tarkastelluista kuvakirjoista toteuttaa lastenkirjoille tyypillistä kaavaa asettamalla päähenkilöksi tai fokalisoijaksi lapsen tai lapsenomaisen eläinhahmon. Lapsihahmojen ympärille rakentuvat tässä artikkelissa käsitellyistä kirjoista esimerkiksi A Brain is for Eating, Zombies Love Brains, Peanut Butter Jelly Brains, That's Not Your Mommy Anymore, Zombies - the Stinking Dead sekä My Bunny is a Zombie ja If I Were a Zombie. Lapsiin viittaavat myös jo nimen perusteella Baby's First Survival Guide, Zombie Kids ja Babies' First Book of Zombies. Sillä, kenen kautta tarina kerrotaan, on merkitystä myös kirjojen kohderyhmän ja lastenkirja-statuksen määrittämisessä. Kuvakirjat luetaan usein osaksi lastenkirjallisuutta jo niiden formaatin perusteella, mutta lisäksi viitteen kohdeyleisöstä tarjoaa usein esimerkiksi tarinoiden keskeisten toimijoiden ikä. Tätä havainnollistaa esimerkiksi $A$ Brain is for

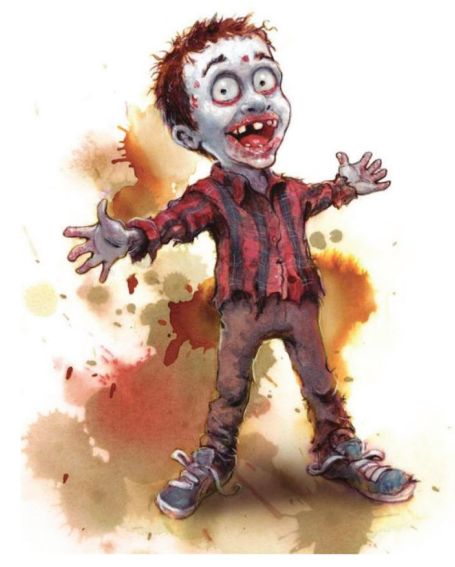

A brain is for eating

Yes, that's what I said

Kuva 2. Kirjasta Dan \& Amelia Jacobs, A Brain is for Eating, kuvittanut Scott Brundage, julkaisija Pale Dot Voyage. (C) Scott Brundage.

Eating (Jacobs \& Brundage 2013). Se alkaa aukeamalla, joka esittää vasemmalla sivulla zombiutuneen, selvästi iloisen lapsen ja oikealla tekstin "A brain is for eating / Yes, that's what I said".

Teksti ja kuva yhdessä asettavat siis puhujaksi zombilapsen, joka näkökulman kautta kirja antaa erilaisia ruokailua koskevia neuvoja sen (oletetusti yhtälailla zombiutuneelle) lukijalle. Zombies Love Brains (Drysdale \& Kloran 2016) seurailee tätä iloisten lapsizombien esittämisen tapaa ja nostaa päähenkilöiksi kolme sisarusta, joiden zombileikki sisältää aivojen kuolaamista, yössä hoippumista ja normaali-ihmisten puremista, kunnes se tyssää vanhemmaksi paljastuvan "zombin" asettamaan, aikuiskertojan kasvattavalla äänellä kerrottuun, ekplisiittisesti nuoria zombeja puhuttelevaan sääntöön: "toisten aivoja ei saa syödä ilman näiden lupaa"31 Näissä tarinoissa korostuu siis myös lapsille suunnatuille kirjoille tyypillinen opettavaisuus.

Samaistuttavuudesta huolimatta zombien esittäminen tukeutuu usein myös juurikin här- 
but you can't eat someone's

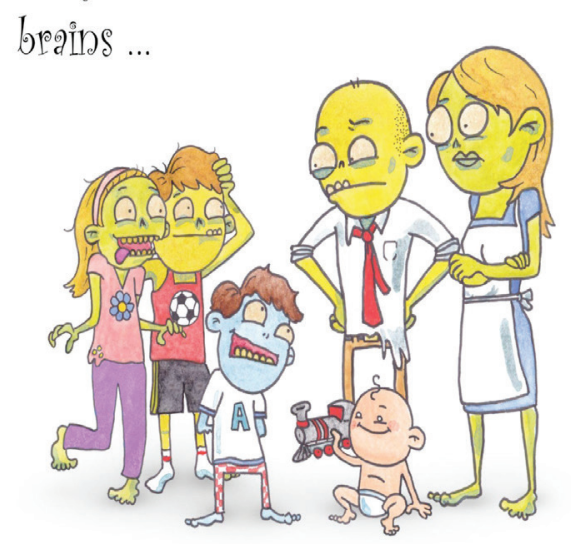

20

Kuvat 3. Kirjasta Colin M. Drynsdale, Zombies Love Brains, kuvittanut Mike Kloran, julkaisija Pictish Beast Publications. (c) Mike Kloran.

mistävään, ruumiillistavaan naurettavaksi tekemiseen. Tämä naurettavaksi tekeminen havainnollistuu paitsi irtoavissa raajoissa, myös yleisessä siivottomuudessa ja kömpelyydessä. Zombies: The Stinking Dead esimerkiksi paneutuu eritoten siihen, miten pahalta zombit haisevat ("like rotten eggs inside a sweaty shoe!"). Zombikuvakirjoissa näytetään myös paljon ikeniä, hampaita, avohaavoja ja sisäelimiä - eritoten aivoja. Zombie Kids sisältää jopa lihakauppa-kohtauksen, jossa zombilihakauppias paloittelee asiakkailleen inmisten raajoja tekstin kuvatessa tilannetta sanoin: "There's an old zombie butcher / who does all the chopping. / Then places them on a / fresh pizza as topping. Humoristisuudessaan nämä "iloiset paloittelut" näyttäisivätkin seurailevan karnevaalinaurulle tyypillistä esitystapaa. Härmistämisen kohde on niissä kuoleman tuntematon ylevyys.

Babies' First Book of Zombies ja Baby's First Survival Guide härmistävät nekin omilla tavoillaan sekä kuvakirjojen lapsiystävällisyyden vaatimusta, että aivan varhaisinta lapsuutta, vauva- ja taaperoikää, eli ajanjaksoa, jolloin inmisen ajatellaan usein olevan viattomimmillaan. Babies' First Book of Zombies tekee tämän vertaamalla vauvoja zombeihin. Baby's First Survival Guide puolestaan suuntaa härmistävän otteensa itse söpöilyn vaatimukseen ja esittelee zombiapokalypsin tekijöitä karun digijäljen ja liioitellun suoraviivaisuuden kautta.

\section{Posthumanistisia tulkintoja ja söpöilyä}

Afro-karibialaisen orjan tai työläisen lisäksi zombi on yhdistetty milloin ghouliin, arabimytologian ihmislihaa syövään, tahtonsa menettäneeseen epäkuolleeseen ${ }^{32}$ tai henkiin, jotka ottavat haltuunsa kuolleen ruumiin. Populaarikulttuurissa zombiutumisen on lisäksi kuvattu tapahtuvan paitsi magian, myös psykologisen ehdollistamisen (esim. tohtori Caligarin mesmerismi) ja teknologian tai biologisen/kemiallisen onnettomuuden kautta. ${ }^{33}$ Eräät zombitutkijoista esittävätkin, että hahmo voi olla zombi, jos 1) sitä sellaiseksi kutsutaan (myös vaihtoehtoiset nimet, kuten "walker", "roamer", "shuffler" ja "biter" kel-
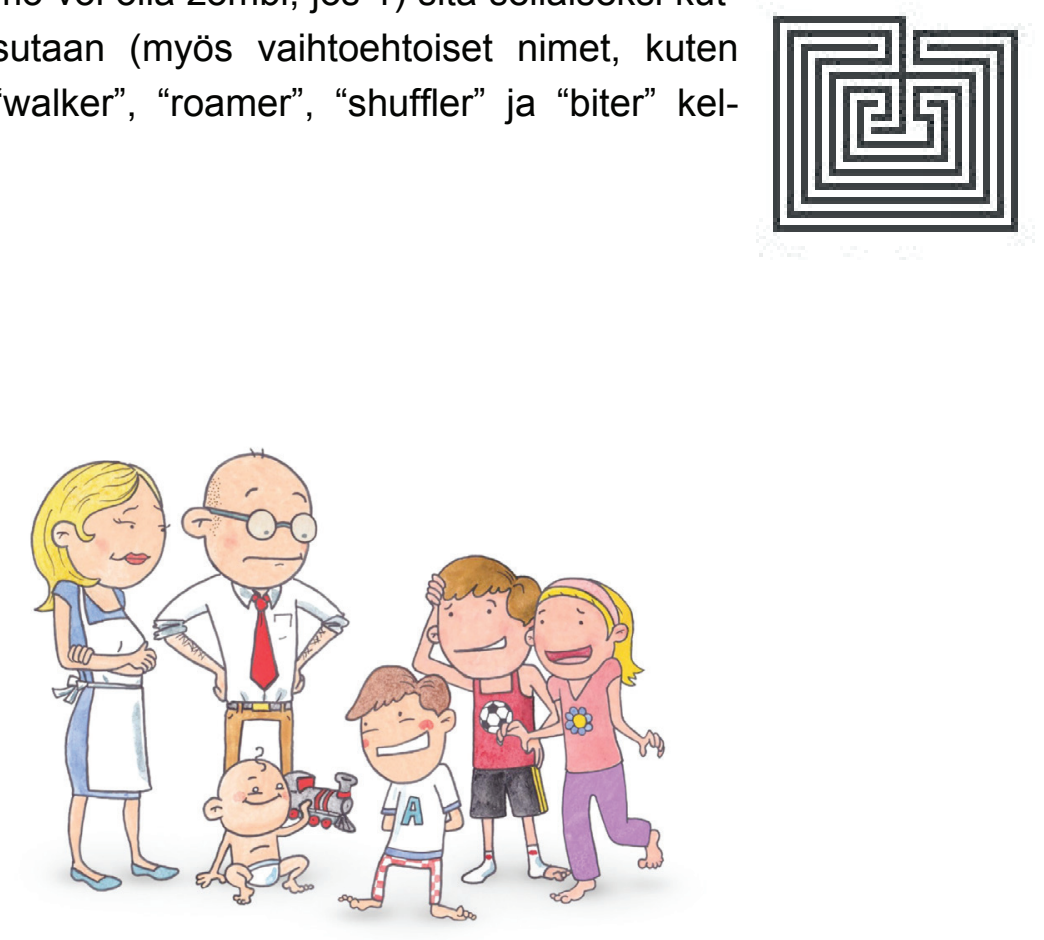

... Without their perprissior! 
paavat); 2) jos se näyttää zombilta (eli inhottavalta elävältä kuolleelta); 3) jos se hyökkää elävien kimppuun ja puree sekä syö näitä tartuttaen zombiuttaan; 4) jos se on sinnikäs, hellittämätön ja 5) aivoton tai tyhmä; 6) jos se liikkuu laumoissa ja 7) jos sen voi tappaa (tai jos se tappaa) ilman rankaisun tai moraalisten seuraamusten pelkoa ${ }^{34}$. Sosiohistoriallisten, zombeja erinäisten ajankuvaan sopivien kriisien ilmentyminä tarkastelevien, zombiselitysten rinnalle onkin noussut myös psykologis-filosofisia näkemyksiä, joiden hengessä zombin määritelmää voidaan etsiä nimenomaan jonkin metafyysisen ominaisuuden puuttumisesta, ontologisesta erilaisuudesta ${ }^{35}$.

Tämä ontologinen erilaisuus liittää zombin hahmon lapsuuden sosiologiaan. Kysymys siitä, kuka kirjassa kuvataan zombina on olennainen siksi, että zombi on hahmona hirviö, määritelmällisesti ulkopuolinen ja kauhistuttava esimerkkitapaus. Sen, kenet tarinoissa zombiutetaan tai muutetaan eläimelliseksi tai hirviömäiseksi, voidaan siis nähdä kertovan siitä, ketä niissä toiseutetaan ${ }^{36}$. Tapauksissa, joissa suurin osa protagonisteista on zombeja ja zombius on ei-pelottava normi, tällainen analyysi saattaa tosin tuntua jokseenkin harhaanjohtavalta. Lisäksi lasten toiseuttamista pehmentävät ja peittävät usein huumori ja kuvaustavan tavallisuus. Vaikka zombius liitettiin zombiviihteen alkuaikoina ennen kaikkea primitiivisyyteen ja toiseutettuihin kansoihin tai inmisryhmiin, se on nykyään jo pitkään käsitellyt kysymystä siitä, miten toiseus määritellään, kun se tulee hyvin lähelle omaa verrokkiryhmää ${ }^{37}$. Kun zombiuttamisen kohteiksi nousevat yhä tutummat ja läheisemmät hahmot, ei siis ole inme, että sen kohteeksi joutuvat myös lapset, jotka muutenkin kuvataan länsimaisessa kulttuurissa usein humoristisesti pieninä hirviöinä ${ }^{38}$.

Zombien ontologinen erilaisuus voidaan kuitenkin nähdä myös voimavarana. Dan ja Amelia Jacobsin A Brain is for Eating toteuttaa eräänlaista posthumanistista otetta valitessaan zombilasten näkökulman ja puolustaessaan sitä myös eettisten pohdintojen muodossa. Elävät inmiset esitetään tässä tekstissä "paketteina" jotka ovat ruokaa ja sisältävät herkuksi määriteltyjä aivoja. Pysähtynyt koulubussi tarjoaa näin ollen "monta ateriaa" ja eräät paketeista (raskaana olevat naiset) saattavat sisältää jopa kaksin verroin aivoherkkua. Tarinan eettinen huippukohta saavutetaan lopussa, jossa kuvataan sitä, miten jotkut paketit taistelevat ja huutavat, etteivät halua kuolla. Tässä yhteydessä empaattisen nuoren zombin on riimin mukaan kuunneltava vatsaansa, jonka käsky on selkeä ja toistaa kirjan nimeä: aivot on luotu syötäväksi. Kirjan viimeinen aukeama paljastaa, että lopputuloksena tämän ohjeen seuraamisesta on epäkuolleiden varsin onnellisen tai tavallisen oloinen valtakunta.

Jo mainittujen teosten lisäksi zombilapsen ajatusten ympärille rakentuu myös Joe McGeen ja Charles Santoson Peanut Butter Jelly Brains (McGee \& Santoso 2015). Kirjan päähenkilö, zombipoika nimeltä Reginald, on klassinen outolintu, mutta outoa hänessä ei ole se, että hän on zombi, vaan se, ettei hän haaveile aivoista, kuten muut zombilapset. Muiden ajatellessa vain aivoja, Reginald haluaa maapähkinä- ja hillovoileipiä. Ja kun muut zombit tarinan kohokohdassa sitten ymmärtävät voileipien arvon ja lopettavat aivojahtinsa siirtyen syömään näitä inmisystävällisempiä herkkuja, alkaa Reginald erilaisuudessaan heti haaveilla pitsasta.

Kirjan kohdeyleisön ja sen lastenkirja-statuksen kannalta on olennaista, että suurin osa sen kuvaamasta zombilaumasta näyt- 
PIZZA.

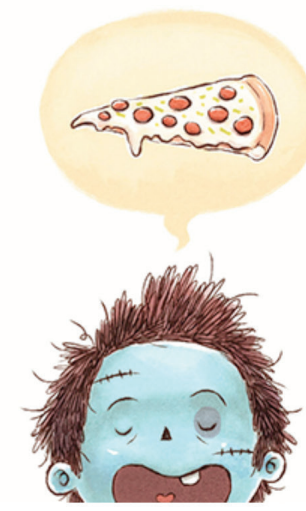

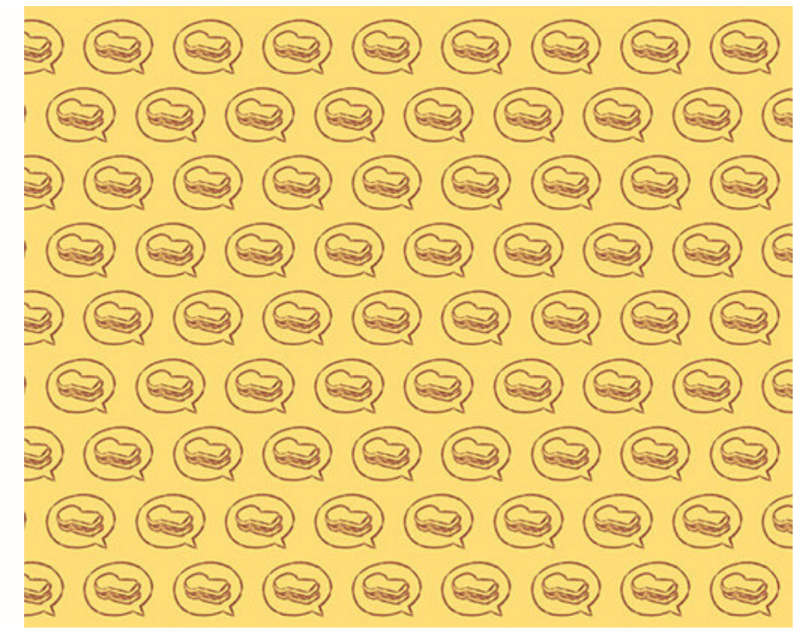

Kuva 4. Kirjasta Joe McGee, Peanut Butter Jelly Brains, kuvittanut Charles Santoso, julkaisija Abrams Books. (c) Charles Santoso.

täisi olevan lapsia, kooltaan pienempiä kuin esimerkiksi kaupan täti tai kaupunginjohtaja. Mukana on jopa yksi zombitaapero. Kirjan esteettisen linjan voidaan puolestaan katsoa edustavan estetisointia, sillä kuolema ei näy sen söpöissä zombihahmoissa muutoin kuin sinisenä ihonvärinä, rispaantuneina vaatteina ja kliseisinä Frankenstein-arpina.

Samanlaista estetisoivaa linjaa edustaa myös My Bunny is a Zombie (Wilson \& Al-Chalabi 2017). Sen päähenkilö, tyttölapsi nimeltä Bethany, on tavallinen, elävä lapsi, jonka status määrittyy tämän suhteesta tarinan isään ja äitiin sekä pupu-leluun, josta vanhemmat haluavat päästä eroon, mutta jonka Bethany pelastaa auton alta ja pitää itsellään vaikka se on puolikuollut, rispaantunut ja haiseva, eikä edes erityisen fiksu. Tässäkin tapauksessa kuvitusta hallitsevat pastellisävyt ja pehmeät, pyöreät muodot ja tekstiä pehmentävät hellittelysanat, kuten "sweetie", "honey", "daddy" ja "bunny".

\section{Satuhahmoja ja aikuisia puhuttelevia parodioita}

Selkeästi satuhahmoina tai kuvitelmina zombit esitetään vain kolmessa tämän otoksen kirjoista: Mike Kloranin kirjassa Zombies, the
Stinking Dead (Kloran 2014), erilaisia satuhahmoja listaavassa If I Were a Zombie -kirjassa (Inglis \& Orchard 2016) sekä jo edellä mainitussa My Bunny is a Zombie -kirjassa. If I Were a Zombie -kirjassa zombi on vain yksi osa hahmogalleriaa, joka kattaa satuhahmoja jättiläisistä keijuihin, vampyyreihin, noitiin, kummituksiin ja merihirviöihin. Erona varsinaiseen kauhuviihteeseen tässäkään kirjassa ei lopulta tematisoida

Kuva 5. Kirjasta Joe Wilson, My Bunny is a Zombie, kuvittanut Ammar Al-Chalabi, julkaisija Talk of the Tavern Publishing Group. (c) Ammar Al-Chalabi.

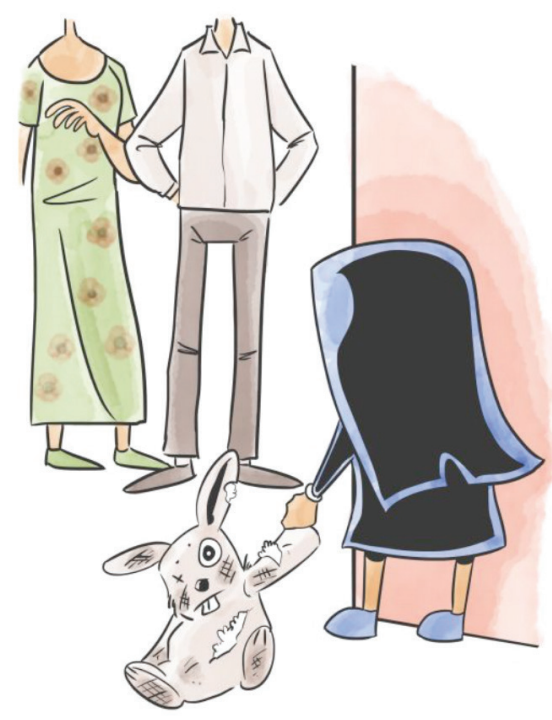


erityisemmin juuri kuolemaa, vaan zombi on yksinkertaisesti satuhahmo muiden joukossa.

Taiteen ja taikauskon osalta kysymys kirjojen kohderyhmästä muuttuu kiinnostavaksi, kun edellä mainittuja satuolentoja lähestytään uskomuksina, joita sekularisoitunut, rationalismia painottava länsimainen kulttuuri pyrkii pitämään yllä lapsissa vain tiettyyn ikään asti. Ikäraja, jonka jälkeen näitä uskomuksia pyritään aktiivisesti purkamaan, on liukuva, mutta se voidaan sijoittaa esimerkiksi kuudesta kahdeksaan ikävuosien kieppeille. ${ }^{39}$ Onkin mielenkiintoista, että samoihin aikoihin, kun uskoa joulupukkiin ja hammaskeijuun aletaan lasten kasvaessa purkaa, aletaan pelottavampia yliluonnollisia hahmoja käsitellä lastenkirjallisuudessa selkeästi enemmän. Tässä käsitellyistä kirjoista Zombie Kids (Dweck \& Draisey 2012) on esimerkiksi varustettu $6+$ ikäsuosituksella ja se on julkaistu KiteReaders-sarjassa, joka pyrkii kirjan sisäkannesta löytyvän "mission statementin" mukaan parantamaan lasten lukutaitoa. Populaarikulttuurisen asemansa vuoksi zombin hahmoa voidaankin ilmeisesti käyttää vetonaulana, jolla lapsia houkutellaan lukemaan iässä, jossa he siirtyvät lapsellisemmista us- komuksista pelottavampien fantasiahahmojen pariin.

Zombien tuomista kuvakirjaformaattiin voidaankin pitää myös inkongruenssihuumoriin tukeutuvana kategoriarikkomuksena, sillä väkivalta, joka, kuten yllä kuvattiin, liittyy zombeihin monella tapaa niin niiden symboliikan kuin myös niiden kannibalistisen toiminnan osalta, on nykyisten lapsikäsitysten vallitessa pyritty pitkälti rajaamaan ulos lastenviihteen piiristä. Zombikuvakirjat, joissa väkivaltaan ja väkivaltaiseen kuolemaan tartutaan selkeimmin, onkin melkein-

Kuva 6. Kirjasta Michael Teitelbaum, The Very Hungry Zombie, kuvittanut Jon Apple, julkaisija Skyhorse Publishing Inc. (C) Jon Apple.

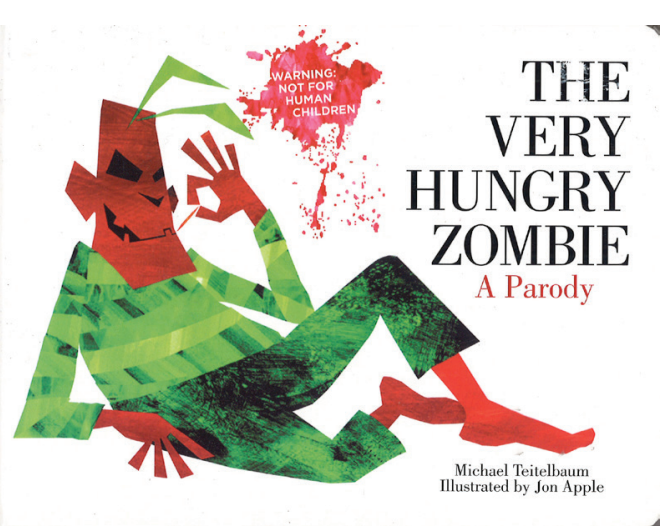

pä poikkeuksetta suunnattu aikuisyleisöille ja ne parodioivat joko lastenkirjallisuutta tai kauhuviihdettä tai kumpaakin. Klassikkokuvakirjaa The Very Hungry Catepillar parodioiva The Very Hungry Zombie: A Parody (Teitelbaum\& Apple 2012) tarjoilee esimerkiksi jo etukannessa varoitustekstin "Warning: not for human children". Varoitusteksti on sijoitettu punaiseen roisketahraan, joka herättää mielikuvan verestä. Kirjan pääpaino on sen esikuvan mukaisesti syömisen kuvauksissa, mutta syötäväksi joutuvat kannibalistisessa hengessä eri

Kuva 7. Kirjasta Isabel Atherton, Zombie Cat, kuvittanut Bethany Straker. (C) Bethany Straker.

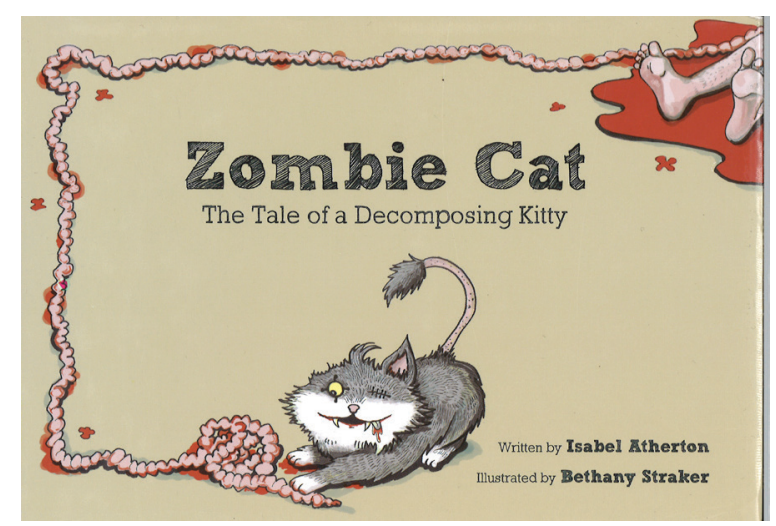


Three little zombies

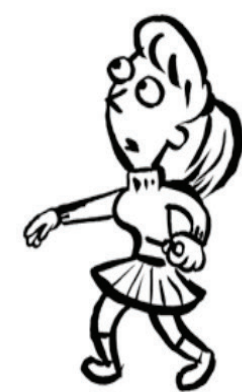

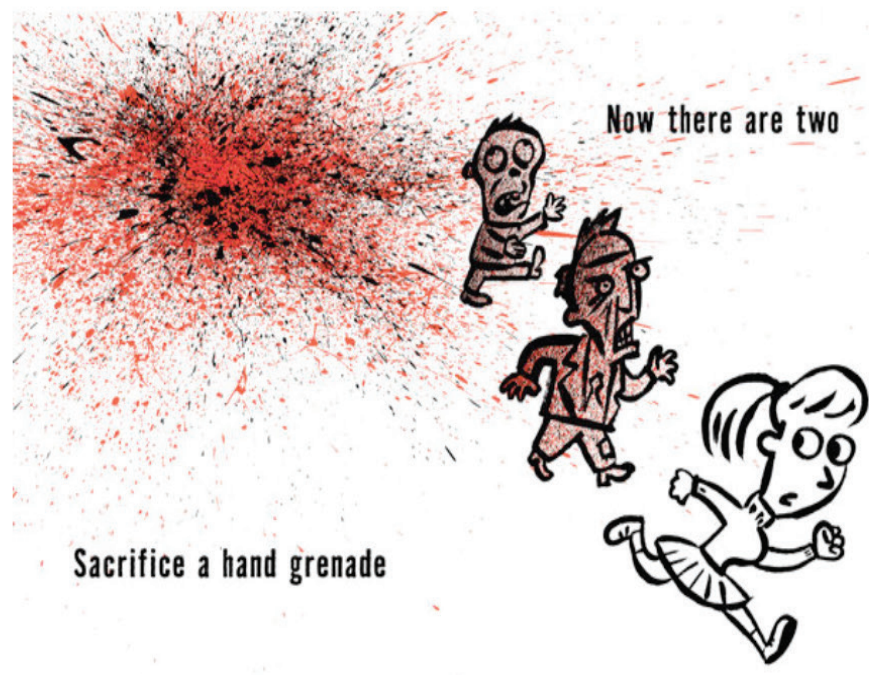

Kuva 8. Kirjasta Andy Rash, Ten Little zombies. (c) Andy Rash.

ammattikuntia edustavat inmiset ja ihmisten ruuminosat tavanomaisempien herkkujen sijaan.

Makaaberimpaan ilmaisuun keskittyvät myös Zombie Cat (Atherton \& Straker 2012) ja Ten Little Zombies (Rash 2010). Zombie Catin päällimmäinen teema on tosin edelleen lastenkirjojen hengessä ystävyys, mutta jo sen kansikuva viittaa siihen, että zombius voi asettaa zombiutuneen eläimen ja tämän omistajan ystävyyden koetukselle. Samalla teemalla leikittelee tavallaan myös Ten Little Zombies, joka kantaa alaotsikkoa $A$ Love Story. Siinä lahdataan zombeja muun muassa moottorisahalla ja käsikranaatil- la, kunnes kohdalle tulee oma zombiutunut tyttöystävä. Olennaista on, että näissä kirjoissa ei vältetä veren kuvauksia ja että päähenkilöt ovat aikuisia. Esitystapa on edelleen humoristinen, mutta siinä on pistävyyttä ja ruumiillisuutta, jota selkeämmin lapsille suunnatut kirjat välttävät.

Mogkin ja Wellsin That's Not Your Mommy Anymore (Mogk \& Wells 2011) sisältää jopa niin sanottua unheimlich-outoutta, joka usein liitetään myös nimenomaan zombeihin ${ }^{40}$. Tässä kirjassa kertojaääni puhuttelee lukijaa/ kuulijaa sinuna ja olettaa lukijan samastuvan tarinan lapsihahmoon, jonka äiti kokee pelottavan muodonmuutoksen säyseäsil- mäisestä, kauniisti laulavasta ja hyvin leipovasta kotiäidistä kassaneitiä purevaksi, laahustavaksi ja korisevaksi hirviöksi. ${ }^{41}$ Mikäli karnevalismin sijaan tai lisäksi halutaan korostaa zombiutuneen äidin pelottavuutta ja outoutta, voidaan sanoa, että äitihahmo (rakastettu ja jopa pyhäksi mielletty auktoriteetti) on tässä kuvaustavassa härmistetty, eli outoutettu ja alentavasti ruumiillistettu. Huomionarvoista on, että That's Not Your Mommy Anymore -kirjan kuvittaja Aja Mulford (ent. Wells) huomautti kuvan käyttölupaa myöntäessään, ettei tätä kirjaa ollut tarkoitus suunnata lapsille. Samanlaisen muistutuksen tarjoili myös Ten 
Little Zombies -kirjan tekijä Andy Rash. ${ }^{42}$ Mitä pelottavampia kuvakirjojen zombit ovat ja mitä selkeämmin ne tematisoivat kuolemaa ja väkivaltaa, sitä helpommin ne siis ilmeisesti luetaan aikuisille suunnatuiksi huumorikirjoiksi varsinaisten kuvakirjojen sijaan.

\section{Härmistetty, hallittu yliluonnollisuus}

Zombies: The Stinking Deadin kirjoittanut ja kuvittanut Michael Kloran kertoo kirjan johdannossa, kuinka zombien piirtäminen on auttanut häntä pääsemään yli zombipelostaan. Lapsena hän kertomansa mukaan pelkäsi zombeja enemmän kuin mitään muita hirviöitä, mutta saadessaan pyhäinpäivänä koulussa tehtäväksi piirtää lempihirviönsä hän piirsi zombeja ja huomasi, että piirretyt zombit olivat oikeastaan "aika makeita" (awesome). Tämä makeus ei kuitenkaan ole viileyttä supersankarien, kuten Batmanin tai He-Manin, tai näiden ultimaattisten antagonistien, kuten Jokerin tai Skeletorin hengessä. Vastausta siihen, mistä zombien "makeus" johtuu, pitääkin nähdäkseni etsiä juuri niiden rumuuteen, typeryyteen ja kömpleyyteen nivoutuvasta inhottavuudesta.
Siitä, voidaanko zombikuvakirjoissa havainnollistuvaa estetisointia ja esteettistä härmistämistä pitää erityisen lapsellisina pelon hallinnan keinoina, voidaan olla montaa mieltä. Kuvamagiaan liittyvä animismi on tosin rationalismin aikakaudella liitetty usein ennen kaikkea lapsiin ja primitiivisiin kansoihin ${ }^{43}$, mutta tätä käsitystä on myös kyseenalaistettu 1930-luvulta lähtien ${ }^{44}$. Nykytutkimus painottaa sitä, ettei taikauskoinen suhtautuminen ole suinkaan vain lapsille

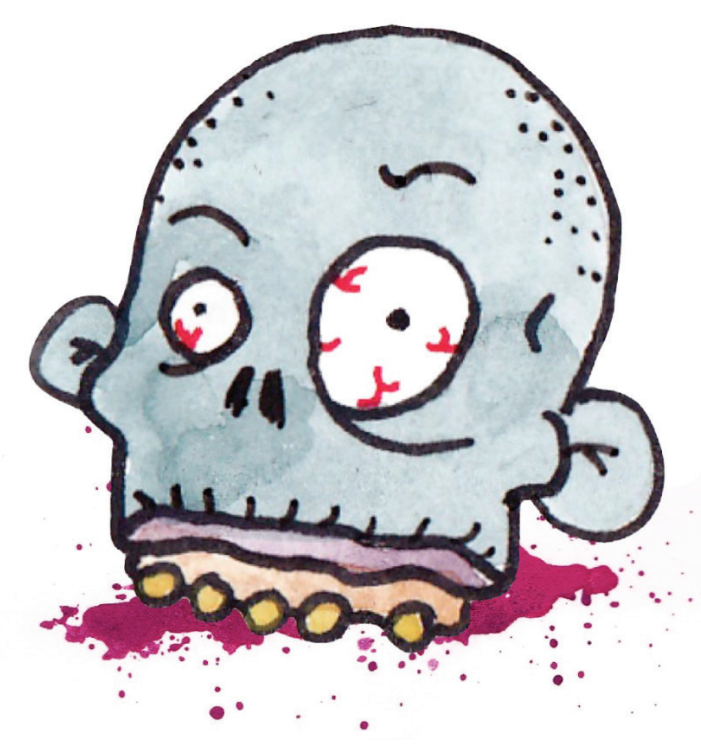

Kuva 9. Kirjasta Mike Kloran, Zombies: the Stinking Dead (c) Mike Kloran. ominaista tai sisäsyntyistä, vaan myös pitkälti kulttuurisesti tuotettua. ${ }^{45}$ Yhteisöjen ja kulttuurien voidaan esimerkiksi katsoa vaikuttavan siihen, minkälaisia tarinoita lapsille tai lastenkulttuuriin tai yliluonnollisuuteen liittyen kerrotaan. Vaikuttamisen keinoja ovat esimerkiksi salliminen ja rohkaisu tai kieltäminen, ja ne voivat kohdistua esimerkiksi tarinan totuudenmukaisuuteen tai liioitteluun, moraalisiin tekijöihin (kuten kerskailu/ vaatimattomuus) tai fantasiaelementteihin. ${ }^{46}$ Silti käsitys lasten luontaisesta taikauskoisuudesta näyttäisi juurtuneen syvälle nykyisinkin arkipuheessa vallitseviin lapsikäsityksiin. Maria Laukka esimerkiksi esittää, että lapsi suhtautuu kuvaan animistisesti ja tunteellisesti ja saattaa esimerkiksi suudella tai sylkeä sitä taikka repiä sen ja sotkea peikon kasvot. Lisäksi Laukka väittää, että lapsi "kiinnittää harvoin huomiota kuvan muodollisiin ominaisuuksiin tai erityisiin esteettisiin seikkoihin". ${ }^{47}$

Minä esittäisin kuitenkin, että juuri kuvien muodolliset ominaisuudet vaikuttavat siihen, halutaanko sitä suudella, sylkeä vai sotkea. Mikäli pelottava hahmo, kuten zombi, on jo valmiiksi härmistetty, voidaan ehkä ajatella, että se on jo valmiiksi sotkettu ja siten 
haltuunotettu Lisäksi näyttäisi siltä, että esteettinen härmistäminen on varsin yleinen populaarikulttuurinen, eikä siis mitenkään erityisen lapsellinen, esitystapa. Ovathan zombit populaarikulttuurissa yleensäkin usein nimenomaan kömpelöitä, käveleviksi ruumiiksi redusoituja hahmoja, joilta puuttuvat kaikki korkeammat sielun ja mielen voimat tai petoeläinten sulavuus. Esteettisen härmistämisen käsitettä voitaisiinkin tästä näkökulmasta käsin katsottuna hyödyntää niin kauhuviihteen kuin myös maagisten kuvastojen tutkimuksessa, missä se voisi tarjota tulkinnallisen työkalun esimerkiksi juuri Abry Warburgin demonisaation ja humanisaation ajatusten tai käsitteiden, kuten freudilaisen outouden ja kristevalaisen abjektin rinnalle.

Zombiudelle kuvakirjoissa annettujen tieteellisten ja "lapsellisten" selitysten (kuten ydinvoimalaonnettumuuksien, virustartuntuntojen ja leikin) ja niissä valittujen esteettisten esitystapojen voidaan siis ajatella pyrkivän hallitsemaan kuolemiseen ja yliluonnollisiin hirviöihin liittyviä pelkoja.

Tällaisen kuvallisen pelonhallinnan ja magian tai taikauskon yhteyttä voidaan avata ajattelemalla magian funktioita, eli sitä, mi- ten se palvelee yksilöä tai yhteisöä kognitiivisesti, emotionaalisesti, sosiaalisesti ja adaptoivasti. Avuttomuuden tunteen on havaittu aiheuttavan esimerkiksi masennusta, stressiä ja suorituskyvyn heikkenemistä. Illuusio kontrollista saattaa tällöin tuottaa positiivisia terveysvaikutuksia. ${ }^{48}$ Jos ajatukset samankaltaisuudesta ja positiivisesta kontaminaatiosta tai näkymättömistä voimista voivat auttaa aiemman maailmanmestarin paitaan pukeutuvan urheilijan voittoon, ehkä härmistettyjen tai estetisoitujen zombienkin voidaan katsoa tarjoavan katsojille tai lukijoille jonkinlaista positiivista hallinnan tunnetta suhteessa vaikkapa stressiin ja väsymykseen, jotka tekevät meistä eräänlaisia "zombeja" arjessa.

Haluaisinkin lopuksi painottaa vielä sitä, etteivät zombikuvakirjoissa käytetyt pelon ja yliluonnollisen hallinnan tavat lopulta eroa suuresti siitä, miten pelkoja ja yliluonnollisuutta hallitaan nykykulttuurissa yleensä. Kun zombit esitetään söpöinä tai inhottavina ja naurettavina, niissä ruumiillistuva yliluonnollinen uhka kotoistetaan tavalla, joka tekee siitä hallittavan, hassun ja jopa kivan, makean. Näin zombitrooppia kierrätetään ja ylläpidetään populaarikulttuurissa, ilman että sen toiseuttavat, magiaan ja yliluonnolliseen liittyvät juuret ja kuolemaa tematisoivat kysymykset otetaan vakavasti. Lopulta kuvakirjazombit ovatkin ei-vakavasti otettavia juuri hallitun yliluonnollisuutensa vuoksi, oli hallinnan mekanismi sitten lapsiystävälliseksi mielletty estetisointi tai makaaberimpi esteettinen härmistäminen.

\section{Viitteet}

1 Maria Tatar, "Why Fairy Tales Matter: The Performative and the Transformative", Western Folklore 69:1 (Winter 2010), 55.

2 Michelle Ann Abate, Bloody Murder: The Homicide tradition in Children's Literature (Baltimore: Johns Hopkins University Press, 2013).

3 Ks. esim. Käpy ry:n kokoama bibliografia

"Lastenkirjat, suru ja kuolema" http:!/lkapy.fi/surevalle/ tukikirjallisuus/lapset-suru-ja-kuolema/, 20.2.2018, sekä Lois Rauch Gibson and Laura M. Zaidman

"Death in Children's Literature: Taboo or Not Taboo?" Children's Literature Association Quarterly vol. 16

no. 4 (1991): 232-234, luettu 13.2.2018, https://muse. jhu edu/article/249230. David Sadler "Grandpa Died Last Night": Children's Books about the Death of Grandparents", Children's Literature Association Quarterly, vol. 16, nro 4 (1991): 246-250, luettu 13.2.2018, https://muse.jhu edu/issue/13378. Päivi Heikkilä-Halttunen, Minttu, Jason ja Peikonhäntä: Lasten kuvakirjoja kipeistä aiheista (Helsinki: BTJ Finland Oy, 2010), 192-197.

4 Susanne Ylönen, Tappeleva rapuhirviö: Kauhun estetiikka lastenkulttuurissa (Jyväskylä Studies in Humanities 2016), s. 56-81.

5 Susanne Ylönen, "Lower than Low: Domesticating the Aeshtetics of Horror in Childish Remakes" teoksessa Max Ryynänen \& Jozef Kovalcik (toim.) 
Aesthetics of Popular Culture (Academy of Fine Arts and Design \& Slovart Publishing Ltd, Bratislava, 2014): 124-149, Elina Drucker, "Collage and Montage in Picturebooks" teoksessa Bettina KümmerlingMeibauer, The Routledge Companion to Picturebooks (London: Routledge, 2018), 51.

6 Noël Carroll, The Philosophy of Horror, or

Paradoxes of the Heart (London: Routledge, 1990).

7 Abate Bloody Murder, ks. eritoten 224

8 Chloé Germaine Buckley, Twenty-First Century Children's Gothic: From the Wanderer to Nomadic Subject (Edinburgh: Edinburgh University Press, 2018), Peter Kostenniemi "Protection and Agency in Children's Gothic. Multiple Childhood(s) in Angela Sommer-Bodenburg's Der Kleine Vampir, LIR.Journal No 9 (2017): 56-76.

9 Carol Nemeroff \& Paul Rozin, "The Makings of the Magical Mind: The Nature and Function of Sympathetic Magical Thinking" teoksessa Karl S. Rosengren, Carl N. Johnson \& Paul L. Harris (eds.) Imagining the Impossible: Magical, Scientific and Religious Thinking in Children (Cambridge: Cambridge University Press, 2000): 1-34, viite sivulla 5.

10 Catherine Lester, "The Children's Horror Film: Characterizing an "Impossible" Subgenre", The Velvet Light Trap, nro. 78 (2016): 22-37, luettu 13.2.2018, https://muse.jhu.edu/article/628733.

11 Edward P. Comentale \& Aaron Jaffe, "Introduction: The Zombie Research Center FAQ" teoksessa Comentale \& Jaffe (eds.), The Year's Work at the Zombie Research Center, (Bloomington, IN: Indiana University Press, 2014): 1-58, ProQuest Ebook Central, viite s. 2. Christie, Deborah \& Lauro, Sarah Juliet (eds.). Better Off Dead: The Evolution of the Zombie as Post-Human (New York: Fordham University Press, 2011): 1-4. ProQuest Ebook Central, viite s. 1.

12 Sandra L. Beckett, Crossover Picrurebooks: A Genre for All Ages (New York: Routledge, 2012).

13 Carolyn Korsmeyer, Savoring Disgust: The Foul and the Fair in Aesthetics (Oxford University Press: New York, 2011).

14 Petri Vuojala, Pathosformel: Aby Warburg ja avain tunteiden taidehistoriaan (Jyväskylä: Jyväskylän yliopisto 1997): 78.

15 Korsmeyer, Savoring Disgust, 135.

16 Sigmund Freud, Totem and Taboo (London:

Routledge 2004): 97-99. Jean Piaget, Judgement and Reasoning in the Child, London:Routledge 2014):

203. ProQuest Ebook Central.

17 Frances S. Connelly, The Grotesque in Western Art and Culture (New York: Cambridge University Press 2012). Valeriano Bozal Fernández (toim.) The Grotesque Factor: Essays (Museo Picasso Málaga, 2012).

18 Julia Kristeva "Fetishishing the Abject" teoksessa Sylvère Lotringer (toim.) More \& Less 2, trans . Jeanine Herman (Cambridge: MIT Press 1999): 1535.

19 Petri Vuojala, Pathosformel: Aby Warburg ja avain tunteiden taidehistoriaan, Jyväskylä: Jyväskylän yliopisto 1997): 75-80.

20 Vuojala, Pathosformel: 76-78.

21 Mathias Clasen, Why Horror Seduces (New York: Oxford University Press 2017).

22 Nevil Drury, Stealing Fire from Heaven: The Rise of Modern Western Magic. (Oxford: Oxford University

Press, 2011): 4. Nemeroff ja Rozin "The Makings of the Magical Mind", 26

23 Christopher Bracken, Magical Criticism: The Recourse of Savage Philosophy (Chicago: University of Chicago Press, 2007): 3. EBSCOhost.

24 Matthew Parris, Scorn: The Wittiest and Wickedest Insults in Human History (London: Profile Books 2017): 4-5.

25 Elizabeth McAlister, "Slaves, Cannibals, and Infected Hyper-Whites: The Race and Religion of Zombies" Anthropological Quarterly, vol. 85 nro. 2 (2012): 457-486, viite s. 469. Vuckovic, Jovanka, Zombies: Die illustrierte Geschichte der Untoten (München: Knesebeck, 2012): 25, aus dem
Englischen von Ulrike Kretschmer.

26 Franck Degoul "'We are the mirror of your fears": Haitian Identity and Zombification" teoksessa Christie, Deborah \& Lauro, Sarah Juliet (eds.) Better Off Dead: The Evolution of the Zombie as Post-Human (New York: Fordham University Press, 2011): 24-38. Chera Kee, "'They Are Not Men...They Are Dead Bodies!":

From Cannibal to Zombie and Back Again" teoksessa Christie, Deborah \& Lauro, Sarah Juliet (eds.) Better Off Dead: The Evolution of the Zombie as Post-

Human. (New York: Fordham University Press, 2011): 9-23. McAlister, "Slaves, Cannibals, and Infected Hyper-Whites", 472

27 "Using a magic ritual of hugs and tea party, Bethany revived the bunny as a zombie 28 Christie \& Lauro Better Off Dead, 1

29 Mc Alister "Slaves", 467-468.

30 Kevin Boon, "And the Dead Shall Rise" teoksessa Christie, Deborah \& Lauro, Sarah Juliet (eds.) Better Off Dead: The Evolution of the Zombie as Posthuman (New York: Fordham University Press): 5-8. Kee "They Are Not Men...They Are Dead Bodies!", 17. 31 "But in your new state... / ... as one of the undead, / don't let your hunger for brains... / ...go to your head. / For even young zombies... / ...must obey one simple rule, / it cannot be broken... / ...no matter how much you drool. / I know that you feel... / ...like you're on a mission, / But you can't eat someone's brains... ...without their permission!"

32 Ahmed Al-Rawi, "The Mythical Ghoul in Arabic Culture" Cultural Analysis 8 (2009): 45 - 69.

Luettu 13.2.2018, https://www.researchgate.net/ profile/Ahmed Al-Rawi/publication/277816715 The Mythical Ghoul in Arabic Culturel inks/5574cecf08ae7536374ff1e6/The-MythicalGhoul-in-Arabic-Culture.pdf

33 Boon, "And the Dead Shall Rise".

34 Comentale \& Jaffe, "Introduction", 46.

35 Boon, "And the Dead Shall Rise".

36 ks. tästä lisää esim. Maria Lassén-Seger,

Adventures into Otherness: Child Metamorphs in Late 
Twentieth-Century Children's Literature. Turku: Åbo Akademi University Press, 2006, 35.

37 Kee, "They Are Not Men...They Are Dead

Bodies!", 16.

38 Karen Coats \& Farran Norris Sands, "Growing up Frankenstein: Adaptations for Young Readers" teoksessa A. Smith (Ed.), The Cambridge Companion to Frankenstein (Cambridge: Cambridge University Press, 2016): 241-255.

39 Karl S. Rosengren \& Anne K. Hickling,

"Metamorphosis and Magic: The Development of

Children's Thinking About Possible Events and

Plausible Mechanisms" teoksessa Rosengren et al.

(eds.) Imagining the Impossible: Magical, Scientific, and Religious Thinking in Children. Cambridge: Cambridge University Press. 2000): 75-98, viite s. 87 40 Sigmund Freud The Uncanny, Penguin Classics -painos (London: Penguin Books, 2003). Masahiro Mori, "The Uncanny Valley", translated by Karl F. Dorman \& Norri Kageki, IEEE Robotics and Automation Magazine, June 2012: 98-100.

41 "When she bites the checker at the store, that's not your Mommy anymore."

42 Aja Mulford, Facebook-messenger viesti kirjoittajalle 7.3.2018. Andy Rash, sähköposti kirjoittajalle 1.3.2018

43 Freud, Totem and Taboo: 97-99. Piaget, Judgement and Reasoning in the Child: 203.

Lauri Ockenström, Talismaaneja, tulenliekkejä ja taivaallisen heijasteita: Marsilio Ficinon kuvamagian taustat ja hermeettinen perinne (Jyväskylä:

Jyväskylän yliopisto 2015): 42-43.

44 Margaret Mead, "An Investigation of the Thought of Primitive Children, with Special Reference to Animism", Journal of the Royal Anthropological Institute 62, 1932: 173- 190. Luettu 20.2.2018, http: /l www.jstor org/stable/2843884.

45 Karl S. Rosengren, Carl N. Johnson \& Paul L. Harris Imagining the Impossible: Magical Scientific and Religious Thinking in Children (Cambridge: Cambridge University Press 2000)
46 Peggy J. MIller, Julie Hengst, Kristin Alexander \& Linda L. Sperry "Versions of Personal Storytelling/ Versions of Experience: Genres as Tools for Creating Alternate Realities" teoksessa Imagining the Impossible, 243.

47 Maria Laukka, "Sotketut peikon kasvot" teoksessa Korolainen, Tuula (toim.) Kirjaseikkailu: Lasten- ja nuortenkirjallisuuden opas (Helsinki: Tammi, 2001): 64.

48 Nemeroff \& Rozin, "The Makings of the Magical Mind", 26.

\section{Primäärilähteet}

Atherton, Isabel. 2012. Zombie Cat: The Tale of a Decomposing Kitty. Illustrated by Bethany Straker. New York: Skyhorse Publishing

DiPucchio, Kelly. 2011. Zombie in Love. Illustrated by Scott Campbell.

Drysdale, Colin M. 2016. Zombies Love Brains. Illustrated by Mike Kloran. Pictish Beast Publications.

Dweck, Julia. 2012. Zombie-Kids. Illustrated by Mark Draisey. Publisher KiteReaders, Santa Clara CA. http://motherdaughterbookreviews.com/book-reviewzombie-kids-by-julia-dweckl

Enos, Theresa K. 2012 Baby's First Survival Guide: An Alphabet Book of the Zombie Pandemic. Create Space Independent Publishing Platform.

Inglis, Kate. 2016. If I Were a Zombie. Illustrated by Eric Orchard.

Jacobs, Dan \& Amelia. 2013. A Brain is for Eating: A Picture Book for Young Zombies. Illustrated by Scott Brundage. Chattanooga: Pale Dot Voyage: A Humanaut endeavor.
Kloran, Michael. 2014. Zombies: The Stinking Dead.

Knuth, Wendy. 2014. Moore Zombies: the Search for Gargoy. Illustrated by Brian Allen.

McGee, Joe. 2015. Peanut Butter \& Brains: A Zombie Culinary Tale. Illustrated by Charles Santoso. New York: Abrams Books for Young Readers.

Mogk, Matt. 2011. That's Not Your Mommy Anymore: A Zombie Tale. Illustrated by Aja Wells. Berkeley: Ulysses Press.

Rash, Andy. 2010. Ten Little Zombies.

Reich, Justin. 2012. A Baby's First Book of Zombies. Illustrated by Marc Scheff.

Teitelbaum, Michael. 2012. The Very Hungry Zombie: A Parody. Illustrated by Jon Apple.

Wilson, Joe. 2017. My Bunny is a Zombie! Illustrated by Ammar Al-Chalabi. Talk of the Tavern Publishing Group.

FT Susanne Ylönen on jyväskyläläinen taidekasvattaja ja kulttuurintutkija, jota kiinnostavat kauhun ja lapsuuden leikkauskohdat, sekä inhon magneettisuus. Tällä hetkellä Ylönen toimii tutkijatohtorina Jyväskylän yliopistolla ja tutkii esteettisen härmistämisen käsitettä erilaisten populaarikulttuuristen esimerkkitapausten kautta. Tutkimusta rahoittaa Suomen Kulttuurirahasto. 